\title{
LA FAMILIA NUCLEAR ANTE EL DERECHO. UNA RETROSPECTIVA DE SU FORMACIÓN Y DEFINICIÓN EN LA TRADICIÓN JURÍDICA OCCIDENTAL
}

\author{
NUCLEAR FAMILY AND LAW, A RETROSPECTIVE OF ITS FORMATION \\ AND DEFINITION IN THE WESTERN LEGAL TRADITION
}

\author{
Manuel Vial-Dumas*
}

\begin{abstract}
RESUMEN: La estructura nuclear de la familia es recogida por el derecho a través de mecanismos que la definen desde el punto de vista patrimonial. Estas son las que denominamos normas válvula porque permiten reconocer a este grupo al interior de aquel más extenso de los parientes. En este trabajo se identifican dichas normas y se traza su recorrido desde su origen en la Antigüedad tardía hasta hoy.
\end{abstract}

Palabras clave: Familia nuclear, herencia, emancipación, viudedad, historia de la familia, historia del matrimonio.

ABSTRACT: The nuclear structure of the family is collected by law through mechanisms that define it from the patrimonial point of view. These are what we call valve norms because they allow to recognize this group inside of the set of the relatives. In this work, these norms are identified and traced from its origin in Late Antiquity until today.

Keywords: Nuclear family, Inheritance, Emancipation, Widowhood, Family History, Marriage History

\section{INTRODUCCIÓN}

Familia no hay una sola. Decimos ante terceros extraños que un tío, una prima o un cuñado son parte de nuestra familia; no obstante, utilizamos la misma palabra para designar a los miembros de nuestra familia nuclear, excluyendo de este concepto a esos mismos parientes que antes hemos designado como familia. De ahí la histórica ambigüedad del término, pues familia designa no solo una, sino múltiples realidades plurales ${ }^{1}$.

Hay una cosa que sí es cierta: cuando decimos familia siempre lo hacemos para designar un conjunto de elementos y que dichos elementos, hoy, son personas ${ }^{2}$. Estos conjuntos

\footnotetext{
* Doctor en derecho, profesor en la Universitat Oberta de Catalunya. Dirección postal, Av. Carl Friedrich Gauss, 5. 08860 Castelldefels (Barcelona), dirección electrónica: mviald@uoc.edu

1 La etimología de família es incierta. Algunos filólogos derivan la palabra del osco famel; también se alude a famulus que podría provenir del indoeuropeo dhe-mo-s que designa al esclavo que habita en el mismo hogar o a aquellos que pertenecen a la casa. En cualquier caso, como se aprecia en la nota siguiente, la palabra sirve para designar tanto realidades que hoy llamaríamos patrimoniales como también personales. Para un panorama general de esta discusión filológica Gutiérrez (2006) pp. 15-18.

2 En la Antigüedad romana más arcaica, por ejemplo, la palabra familia incluía el patrimonio y en general todo aquello bajo el poder del padre de familia, poder que luego se diferencia respecto de cosas y respecto de personas. El concepto que delimita la unidad de la familia es el poder del padre, se manifieste este en forma de potes-
} 
pueden contenerse unos a otros, pueden unirse o intersecarse, pueden ser concéntricos o incluso provenir de otro grupo de conjuntos, como en el caso del parentesco por afinidad.

Evidentemente, las personas que conforman estos conjuntos están relacionadas entre sí y también estos, en tanto unidades, pueden estarlo con personas individualmente consideradas u otros grupos ${ }^{3}$. Por eso familia no hay una, y lo normal es que una familia nuclear esté rodeada o inmersa en grupos más amplios. No buscamos aquí la existencia o inexistencia de esos grupos. Lo que nos interesa es la traducción jurídica de su forma y contenido, cómo el derecho lee y a la vez configura los distintos conjuntos y las relaciones entre estos que, todos, son familia.

El problema radica en poder reconocer e identificar subconjuntos dentro de ese círculo de parientes y en poder diferenciar esos subconjuntos entre sí. En nuestro caso particular el problema consiste sobre todo en identificar en el ámbito jurídico aquel que nos aboca: la familia nuclear. El objetivo de este trabajo es revisar esa configuración, cómo y cuándo aparece y de qué forma se desenvuelve en el transcurso de la tradición jurídica occidental. Para eso pesquisamos en los orígenes de ciertas instituciones y normas que van moldeando, en el derecho, los contornos de la familia nuclear. La mayoría de ellas aparecen entre los siglos III y VII d.C., en plena reconversión espiritual y económica del mundo antiguo. A partir de esos orígenes remotos, trazamos la historia de dichas normas e instituciones durante el mundo medieval y moderno, la época de la codificación y las consecuencias de las transformaciones que se produjeron en los dos últimos siglos.

\section{LA FAMILIA COMO REALIDAD JURÍDICO-PATRIMONIAL}

La familia es ante todo una realidad moral, podríamos decir metajurídica ${ }^{4}$. Esa realidad moral, no obstante, como muchas realidades morales, tiene una expresión jurídicopatrimonial y es esa expresión la que nos facilita diferenciar entre sí los grupos que son designados con la palabra familia. En otras palabras, estas relaciones basadas en el parentesco o el matrimonio que hemos denominado "morales" (sin hacer caso de que en la mayoría de los casos son también biológicas), suelen tener un correlato jurídico-patrimonial. En buena

tad sobre personas o propiedad sobre cosas. Véase Franciosi (2003) pp. 94-97. Ulpiano, más tarde, cuando el concepto se encuentra más ligado a su componente personal, señala cuatro acepciones: primero, familia como todas las personas sometidas a la potestad del paterfamilias sea por naturaleza o por derecho; segundo, familia como el conjunto de parientes agnados; tercero, familia como conjunto de esclavos; cuarto, familia como todas las personas descendientes de una misma fuente. Véase: D. 50.16.195.1-4; para un estudio comparativo entre los conceptos de familia y domus véase SALLER (1984) pp. 336-355.

3 En sociedades como la occidental contemporánea, con un marcado signo individualista, es más probable que las relaciones que predominen sean de persona a persona y que los conjuntos pierdan definición. En otras sociedades (o en sociedades de otras épocas) los conjuntos se definen mejor y pueden tener una entidad propia que les permite ser sujeto de relaciones jurídicas. Véase SEGALEN (1981).

4 Uso aquí la expresión "moral" en un sentido muy amplio, como aquellas relaciones que socialmente se espera sean dotadas de contenido por lazos de intimidad, afecto o respeto, más allá de si de hecho ello se produce. La metajuridicidad de la familia está dada, en un sentido, por el carácter relativamente inaprehensible de dichas relaciones, y, en otro sentido, por la casuística inabarcable de las expectativas del comportamiento ajeno en el ámbito familiar. El derecho, al menos en su versión codificada, no es capaz de recoger dicho contenido. Por eso, la regulación de la faz patrimonial de la familia ofrece un refugio al intérprete. 
medida, la realidad jurídico-patrimonial es un espejo de la realidad moral. De este modo, normalmente (aunque no necesariamente) donde exista una esfera que denominamos con la palabra familia, existirá también una esfera jurídico-patrimonial, pues esa es, al decir de Bártolo, la cara de la familia que el derecho es capaz de asir ${ }^{5}$.

No quiero decir con esto que el derecho no intente entrar a regir relaciones familiares que no tienen una expresión jurídico patrimonial, ni tampoco que la familia se pueda reducir al plano puramente patrimonial. Sin embargo, debemos convenir que es la faz patrimonial de la familia la que el derecho ha regido por excelencia, más allá de que existan relaciones morales sin contenido patrimonial que sean reconocidas y que el derecho intente disciplinar. Pero para el efecto de definir las esferas que pueden ser denominadas como familia, el derecho patrimonial de la familia es, sin duda, la base más segura. El amor del padre, por ejemplo, y su deber de procurar un bienestar a su hijo ofrece su correspondencia en la obligación que, en algunas tradiciones y épocas, tiene el primero de trasmitir una cuota de su patrimonio a través de la herencia al segundo ${ }^{6}$. Asimismo, por la herencia, la familia de origen de cada cónyuge está patrimonialmente ligada con la que estos han originado. Ambas familias, la de origen y la nueva, suelen ser hoy unidades patrimoniales independientes, pero jamás ajenas. Tampoco son ajenos otros conjuntos jurídico-patrimoniales menos próximos: diremos frente a un extraño que un primo es parte de nuestra familia, aunque el vínculo moral que nos une a él sea generalmente menos intenso que respecto a los padres o hermanos. Asimismo, ese vínculo moral tendrá un correlato jurídico-patrimonial también menos intenso a través de la herencia, pues, si es que le cabe participación en ella, será solo ante la ausencia de otros parientes con los que el derecho presume que se tienen lazos morales (con su correlato jurídico-patrimonial) más intensos.

De esta manera, veremos que cuando usamos la voz familia designamos conjuntos de personas relacionados entre sí y que dichas relaciones no solo son morales, sino también, por regla general, jurídico-patrimoniales. Estas últimas serán normalmente más intensas en la medida que la relación moral que une a uno con otro sea más próxima. En las relaciones jurídico-patrimoniales, están plasmadas las ideas de la familia, de sus funciones, sus prioridades e intereses que han gobernado cada época. En pocas palabras, ellas son normalmente expresión del amor debido.

Cuando utilizo la expresión amor debido, me refiero a una expectativa social de sentimientos y respeto. Estas expectativas responden a innumerables valoraciones, principios, deseos, creencias, prioridades, afectos, etc., que, a la postre, tienen un papel a la hora de distribuir bienes. Por ello, el que exista una relación jurídico-patrimonial nos debe llamar la atención y llevarnos a la pregunta sobre el amor que la ha motivado. Cuando cambia esa relación moral, dicho cambio normalmente imprimirá su huella en el derecho patrimonial de la familia; de forma que esas normas son una pista para interpretar, desde lo patrimonial,

\footnotetext{
5 Bártolo de Sassoferrato lo sentenciaba con claridad en el siglo XIV: "Familia accipitur in iure pro substantia" Bartolus de SaXoferrato (1555) f. 112 rb. D. 28. 2. 11.

6 En sociedades donde el padre puede testar con libertad evidentemente existe una relación moral con el hijo, pero existen otros intereses que confluyen a la hora de la repartición de los bienes, de manera tal que la relación moral con el hijo encontrará otras vías de expresión, tanto en el ámbito jurídico-patrimonial como fuera de él. Para una revisión de esta cuestión Vial-Dumas (2017) pp. 23-44.
} 
el cambio de las relaciones morales. Los padres son siempre padres de sus hijos, pero no es lo mismo serlo en una época que en otra, de esas diferencias es que nos deja constancia el mapa de las relaciones jurídico-patrimoniales. Por eso es útil el acercamiento a la familia y al análisis de sus estructuras desde esta perspectiva; y esto es válido no solo para la familia de hoy, sino para la de cualquier época.

Desde este enfoque, la primera pregunta que hay que hacer es cuáles son los conjuntos que el derecho refleja dentro del conjunto amplio de familiares y las relaciones individuales o colectivas que se tejen entre ellos. El derecho no trata igual a todos los parientes. Dentro de ese grupo amplio existen subconjuntos, a todos ellos en el lenguaje cotidiano los denominamos familia; pero cuando decimos familia respecto de cada uno de ellos designamos realidades diferentes. La respuesta está en algunas instituciones que definen dichos subconjuntos dentro del conjunto amplio de la familia. A esas instituciones podríamos denominarlas normas válvula. Las llamo así porque concentran los flujos patrimoniales en una dirección determinada e impiden la salida de bienes fuera del subconjunto al que sirven de frontera.

En efecto, los cursos sucesorios, por ejemplo, se generan y se extinguen en función de determinados estados civiles; de su generación o su extinción depende que ciertos bienes entren o salgan de un determinado círculo, es decir, de un determinado subconjunto dentro del conjunto de parientes. En nuestro derecho hay ciertas normas que actúan de ese modo. Son reglas que nos permiten observar la existencia de esferas bien definidas, de ciclos de la vida de la familia que el legislador ha establecido como normales. Hoy por hoy estas instituciones parecen naturales $y$, a un jurista que no entienda que el derecho es un producto cultural y por lo tanto un producto histórico, puede parecer que no merecen mayor análisis. Sin embargo, si bien las reglas jurídicas hay que analizarlas en su contexto de vigencia, es aún más importante hacerlo en el momento que nacieron a la vida jurídica. Solo entonces se puede apreciar su real significación. Estas, que ahora me propongo exponer de manera muy panorámica, en el momento de su implantación significaron una gran revolución que configuró la estructura de la familia nuclear en la tradición occidental hasta hoy.

\section{LA FAMILIA NUCLEAR EN EL DERECHO TRADICIONAL, LA EXPERIENCIA OCCIDENTAL ANTES DE LA CODIFICACIÓN}

La supuesta modernidad de la familia nuclear ha sido hace tiempo puesta en tela de juicio. No solo entre los historiadores, que la encuentran en épocas en las que se suponía que casi había desaparecido, también entre los antropólogos que hace algunas décadas abordaron la discusión sobre su carácter natural ${ }^{7}$. Por eso, cuando se señala que el modelo de familia en una determinada sociedad y época corresponde al extenso o al nuclear, lo que se hace en realidad es decir cuál de esos conjuntos tiene mayor preponderancia en ese lugar y en esa época. Por ejemplo, en lo que respecta a la sociedad occidental, hoy se admite

\footnotetext{
7 El debate clásico al respecto está recogido en el trabajo de LÉVI-STrauss (1982) pp. 7-49. también Harris (1984) pp. 262-64 y MURDOCK (1949). Este último reconoce la universalidad de la familia nuclear, pero matiza señalando que las formas alternativas (extensas) de familia son más relevantes en la organización social. Una visión general en SEGALEN (1981).
} 
que la mayoría de las familias europeas durante la alta Edad Media tenían también una estructura nuclear; eso no quiere decir que las estructuras propias de una familia extensa no existieran, sino simplemente que las formas nucleares eran las preponderantes ${ }^{8}$. En esa valoración, el derecho tiene una función primordial, pues, en muchas ocasiones, lo que inclina la balanza del intérprete de la historia de la familia es precisamente la reconstrucción que el derecho hace de la sociedad en la que rige. La cuestión por tanto es saber, primero, si esa familia nuclear tiene una entidad moral lo suficientemente relevante como para que el derecho la reconozca y la refleje y, segundo, cómo identifica el derecho a ese conjunto dentro del conjunto amplio y un tanto indefinido de los parientes.

Si lo que define el conjunto de parientes son relaciones jurídico-patrimoniales, la cuestión es saber qué instituciones nos permiten identificar un conjunto definido de tipo nuclear. Es aquí donde las ya mencionadas normas válvula juegan un papel esencial. Estas normas, en efecto, actúan como válvulas antirretorno, es decir, unas que definen un conjunto relativamente cerrado en cuanto permiten el ingreso de bienes e impiden su salida a otros conjuntos más amplios. Dicho de otra forma, podemos identificar un ámbito de lo familiar con facilidad cuando existen relaciones de parentesco o de matrimonio; pero, para identificar un subconjunto como la familia nuclear, hacen falta criterios adicionales. Dichos criterios pueden ser normas que marcan una dirección en la circulación de los bienes, sobre todo a través de la herencia. Esas normas son válvulas porque determinan que, una vez producido un hecho como la muerte, el matrimonio, la emancipación o el nacimiento de los hijos, el curso natural de determinados bienes cambia y se establece para favorecer a dicho subconjunto de estructura nuclear.

Históricamente el proceso es complejo. Especialmente si al embarcarnos en la historia de Occidente comprobamos que, en el mundo Antiguo, predecesor del nuestro, la familia nuclear como esfera jurídico-patrimonial relativamente independiente -es decir, como un conjunto identificable dentro de las redes de parentesco- apenas tenía entidad jurídica. En efecto, para el derecho romano arcaico y clásico la familia es también una esfera jurídico patrimonial, pero no una esfera de estructura nuclear, sino más extensa ${ }^{9}$. Con esto no quiero decir que la familia nuclear no existiera en la sociedad romana, de hecho, sabemos que la organización familiar más frecuente en la Roma clásica era la nuclear ${ }^{10}$. Sin embargo, la presencia de esta estructura en el ámbito jurídico, e incluso en el lingüístico, era casi nula ${ }^{11}$.

También para el derecho romano la familia era un conjunto de parientes. Aunque, según la definición del jurista Ulpiano, se llamaba asimismo familia al conjunto de cosas y esclavos pertenecientes a una persona. Esto es así porque, para los juristas, la familia era

\footnotetext{
${ }^{8}$ Sobre la familia nuclear en la alta Edad Media entre otros: Toubert (1979) pp. 693 y ss.; Toubert (2006) p. 247, Bonnassie (1979) pp. 225 y ss.; King (1981) pp. 249-277; Ruiz Domenec (1975) pp. 69-123; Guichard (1979) pp. 7-25; Guichard (1998) pp. 287-344; Herlihy, (1985); Fischer Drew (1988); Wickham (2009) pp. 781 y ss, en el caso de Bizancio véase: Laiou (2009) pp. 51-75 ; Kaplan (1992) pp. 483 y ss.; Vial-Dumas (2010) pp. 287-317; Vial-Dumas (2014a) pp. 293-311; Vial-Dumas (2014b).

9 Sobre la familia romana FAYER (1994), ThOMAS (1988) pp. 203-240, FranCIOSI (2003) para un recorrido en las concepciones de la historiografía sobre la familia romana CAPOGRossi (2010) pp. 147-174.

10 Saller (1997) pp. 71-153; Gardner (1998) pp. 6-104

11 SALLER (1984) pp. 336-355.
} 
todo aquello que estaba bajo el poder del pater familias. De modo que el factor que define el conjunto de la familia es dicho poder. Lo que está dentro de la esfera de poder del padre es parte de la familia y lo que está fuera del alcance del poder paterno no lo es ${ }^{12}$.

En ese mismo contexto romano, cuando muere el padre, los hijos dejan de estar sometidos a su poder, pero no por eso dejan de ser parientes. En Roma eran parientes los que estaban sometidos al poder de un antepasado común, los que habían estado sometidos a ese poder y quienes lo hubieran estado si el antepasado común viviese ${ }^{13}$. El parentesco, por tanto, no se define por la generación natural, sino por la pertenencia a una esfera de poder ${ }^{14}$. Esto hace que la definición de conjuntos sea clarísima; el conjunto más amplio es el de los parientes y el más pequeño es el subconjunto de aquellos que están sometidos a un padre de familia, sean estos sus hijos, sus nietos, su mujer o las mujeres de sus descendientes.

Dentro de la esfera de la familia gobernada por el padre, ninguno de los miembros tiene capacidad de goce. Solo el padre es señor de todo lo que en la familia habita y esta propiedad es absoluta, el padre podía disponer de todos los bienes e incluso de las personas, al punto de tener sobre ellas el derecho de dar vida o muerte ${ }^{15}$.

En ese escenario, la familia nuclear, como se ha señalado, no aparece definida como entidad jurídica. En el mundo del derecho la trilogía padre-madre-hijos no constituye por sí sola una esfera propia, distinta a la del padre de familia. El matrimonio no tiene casi efectos en las estructuras familiares. Cuando un padre decide casar a uno de sus hijos, busca una mujer que sale de la esfera de poder de su padre para integrarse en la suya. Lo que ha ocurrido es que un miembro de una familia ha pasado a otra llevando consigo una compensación por las cargas del matrimonio y a la vez un adelanto de la herencia de la mujer: la dote ${ }^{16}$. Pero ninguna esfera ha nacido, ningún conjunto se ha creado a partir del matrimonio ${ }^{17}$.

\footnotetext{
12 Véase nota 2.
}

13 La familia romana comprende a todos los que viven bajo la potestad del pater (família proprio iure), sin embargo, esta extensión puede ser también ficta e incorporar a todos aquellos que han vivido bajo la potestad de un antepasado ya muerto e incluso a aquellos que, sin haber coexistido con el antepasado, estarían bajo su potestad si este estuviera vivo. Esto es lo que conocemos como familia communi iure o familia agnaticia D. 50.16.195.1-4

${ }_{14}$ Se trata de un parentesco agnaticio, gobernado por la voluntad del padre en la medida que él puede decidir quién entra o sale de su esfera de poder y, por lo tanto, quién entra y sale de la familia según los términos descritos en la nota anterior.

15 A menudo la patria potestas del derecho romano tradicional es caracterizada como un poder disciplinario sobre la persona del hijo y se cita como su expresión máxima el derecho vitae nequisque. Lo cierto es que estos poderes son meras expresiones de la esencia de la institución. La patria potestas era el fundamento del parentesco y otorgaba al padre un poder inmenso sobre su descendencia, el poder de determinar quién estaba dentro y quién estaba fuera de la familia. Sobre los orígenes de la patria potestas AmUnÁtegui (2009). Véase también Vial-Dumas (2014b); Veyne (1978) pp. 35-63; Thomas (1988) Thomas (1990); Voci (1985).

16 Para las funciones de la dote véase TregGiari (1993) pp. 323 y ss.; García Garrido (1958)

17 El ejemplo propuesto es de un matrimonio cum manu, usado preferentemente en la época arcaica. En el matrimonio posterior, llamado sine manu, la mujer no pasa a estar bajo la potestad del padre de su marido ni bajo la de su marido si el padre de este ha muerto. Sin embargo, para estos efectos, la estructura es idéntica: la mujer permanece en la esfera de poder de su padre y, por ello, no tiene lugar la creación de ninguna nueva esfera patrimonial. Los conjuntos jurídico-patrimoniales que existían antes del matrimonio son los mismos que existen 
Si no es a través del matrimonio que nacen estos conjuntos que denominamos familia ¿cómo se originan? La respuesta, en el contexto Romano más tradicional, es en el momento de la muerte del padre. Solo la muerte del padre libera al hijo de la potestas y lo convierte en un hombre independiente, en ese momento adquiere capacidad de goce y de ejercicio ilimitadas. Entonces será llamado pater familias, incluso aunque no esté casado ni tenga hijos, pues la familia es la esfera de cosas y personas que está bajo su poder, y para que esa esfera exista no es necesario ni el matrimonio ni los hijos ${ }^{18}$.

\section{HACIA LA FAMILIA OCCIDENTAL, UNA REVOLUCIÓN EN LA HISTORIA DE LA FAMILIA}

No puedo describir con detalle las numerosas fibras que se vieron alteradas durante el largo proceso de cambios que se verificó desde comienzos de nuestra era hasta entrado el siglo VII. Por tanto, debo remitirme a las piezas clave de la nueva estructura que llevará a la familia romana (a la del derecho) de una estructura jurídica patriarcal a una nuclear. Dicha estructura, en sus rasgos esenciales, como veremos, persiste hasta hoy y en ello, las que llamo normas válvula, tienen un papel fundamental. Por qué los romanos en su derecho tradicional no reconocieron la familia nuclear como un conjunto definido es una cuestión compleja a la que no entraré aquí. Baste con decir que, a pesar de su existencia, en la representación jurídica de la realidad social primaron unos intereses, un amor debido, que dejó a la familia nuclear en un lugar secundario, absorbida en su expresión jurídica por la familia extensa, por la estirpe ${ }^{19}$.

En efecto, ya desde comienzos de nuestra era, resulta evidente que las estructuras elementales de la familia romana se veían poco a poco alteradas. La apertura al mundo y las nuevas religiones y filosofías que reinaban en el Mediterráneo provocaron modificaciones en el tejido social que terminaron por reconstruir el aparato estructural de la familia. Y no solo el de la familia, pues en general el marco del antiguo derecho civil se hizo insuficiente para gobernar la nueva realidad compleja del Imperio. Un buen ejemplo es el cambio en las relaciones paterno-filiales. En efecto, al hijo militar le fue concedida una cierta clase de propiedad sobre las ganancias que había obtenido en su servicio militar (peculio castrense). Ese mismo hijo que antes no tenía posibilidad de realizar acto jurídico alguno en su propio nombre y que no tenía capacidad de goce, de pronto puede disponer en vida e incluso testar sobre ciertos bienes ${ }^{20}$. Evidentemente estas novedades supusieron que el hijo fuera acrecentando su independencia respecto del padre. Los juristas romanos identificaban la emancipa-

después del mismo. Una visión de conjunto sobre el patrimonio de la mujer en Roma GarCía GarRIDo (1958) y GarRIDO (1959), véase también Vial-Dumas (2010).

18 D. 50.16 .195 .2 .

19 Esta preponderancia del amor debido a la estirpe y su continuidad puede apreciarse, por ejemplo, en la representación alegórica que hace la Eneida al mostrar a un Eneas que pierde a su mujer en su huida de Troya pero que es acompañado por su padre y por su hijo. Más tarde también la historia lo pone en la disyuntiva de elegir desposar a Dido o continuar con su misión divina. Esta tendencia a superponer el valor del colectivo al del individuo fue puesto de manifiesto ya en el siglo XIX por obras como la de Coulanges (1864)

${ }^{20}$ D.49.17.1-5; CI.12.37.1-6 
ción con la independencia económica, por lo tanto, si el hijo ahora adquiría un cierto grado de dicha independencia, aunque no mediara acto alguno del padre, había que entenderlo también en cierta manera emancipado. En este sentido, la declaración y el efecto de la misma operan en ambos sentidos: se entiende emancipado al hijo que lo es por un acto del padre y con ello adquiere capacidad económica plena, al revés, si un hijo adquiere capacidad económica, se le considera, al menos en el ámbito de esa capacidad, como emancipado ${ }^{21}$.

La decadencia del poder paterno no se produjo solo al interior de la familia, sino también fuera de ella producto de la nueva estructura imperial que transformaba al padre independiente en un súbdito del príncipe. Esta nueva configuración hizo estragos en la figura de la patria potestas ${ }^{22}$. La esfera impermeable que constituía el pater a través de su poder (es decir, la familia) se debilita y su elemento constituyente, que era precisamente ese poder, pierde poco a poco su naturaleza. Como ya señalamos, la generación del parentesco dependía del poder. Estar o hipotéticamente haber estado bajo el poder de un hombre generaba una relación de parentesco con él y los demás sometidos. Sin embargo, el poder ya no será más el único factor que genera el parentesco, poco a poco comienza a ser reconocido el parentesco por sangre en forma paralela. Es una evolución larga hasta que Justiniano eliminó la dualidad de regímenes y estableció el parentesco por generación natural como el único relevante para el derecho sucesorio ${ }^{23}$. Esto nos acerca más a nuestros modelos de familia.

Consecuentemente, el derecho sucesorio también sufrió cambios importantes. Al no ser más el poder, sino la sangre, el factor de definición del parentesco, los cursos hereditarios fueron definiéndose poco a poco a favor de los descendientes. No quiero decir con esto que en el derecho anterior no hayan sido los descendientes el primer orden de sucesión. El problema es otro. En la familia nadie más que el pater ostentaba propiedad, de modo que los bienes con los que se hiciera el hijo, en realidad no le pertenecían y, en el evento de morir, dichos bienes no pasaban a su hijo (es decir, al nieto), sino que volvían al pater, su verdadero dueño. Por otra parte, al morir el padre de familia, los hijos heredaban su fortuna y su posición, pero no la heredaban porque fueran sus hijos, sino porque estaban directamente sometidos a su potestad, la prueba es que el hijo emancipado nada heredaba según el derecho civil. De modo que cuando los juristas reconocen al hijo una especie de propiedad sobre los bienes obtenidos del servicio militar y le permiten testar sobre los mismos, ha comenzado una gran revolución, pues se ha abierto una brecha en la esfera hermética de la familia patriarcal a través de la creación de un subconjunto dentro de ella ${ }^{24}$.

Esta nueva situación de independencia hizo poco a poco normal que el hijo casado configurara junto a su mujer una nueva esfera jurídico-patrimonial. De modo que cuando

\footnotetext{
21 "Cum filii familias in castrensi peculio vice patrum familiarum fungantur", es decir, el hijo actúa como pater familias en lo referente a su peculio castrense: D. 14.6.2 (Ulpiano 64 Ed.). refiriéndose al hijo militar, señala Papiniano "filius duplex ius sustinet, patris et filifamilias", El hijo mantiene dos derechos: el del padre y el del hijo de familia: D.49.17.15.3 (Papiniano 35 quaest.). Veáse Vial-Dumas (2014b) pp. 310-2

22 Herrera (1977) pp. 128-136. Veyne (1978) pp. 35-63

23 Justiniano da por zanjada la cuestión en su Nov. 118. Para antecedentes respecto de los cuales esta novela es el punto de culminante Inst. 3.5.1; 3.3.5; CI. 6.58.15.1; 6.58.14.6; 6.56.7.pr.; 8.58.2; 6.56.6; 6.61.4; 6.59.11; 6.61.6.1c C.th. 5.1.2; 5.1.4; 5.3.1; 8.18.1; 8.18.6; 8.18.10.

24 Véase Vial-Dumas (2014a)
} 
Justiniano (y también los otros legisladores de su tiempo en los reinos romano-germánicos) instituyó la preferencia en la sucesión a favor de los descendientes ${ }^{25}$, lo que hizo fue consolidar dicha esfera impidiendo que los bienes que han entrado en ella, porque son propiedad de los cónyuges (los bienes propios de los cónyuges, la donación nupcial del varón y la dote de la mujer ${ }^{26}$ ), salgan, si no es para favorecer a los hijos. El otro blindaje que consolidó Justiniano, cuyo establecimiento también es fruto de una larga tendencia en este sentido, fue la obligación de dejar una parte de los bienes a los hijos, lo que ya por entonces se denominó porción legítima ${ }^{27}$.

De modo que, en la época del Imperio Cristiano, ya nos encontramos con una familia nuclear como unidad esencial del derecho de familia. Pronto se irán dando otros elementos que terminarán de configurarla, algunos de ellos ya entrados en el medioevo. El más importante de estos elementos es el sistema de transferencias patrimoniales entre cónyuges (o entre sus familias); este es el colofón que sella este proceso de cambio.

Las familias romanas acostumbraban dar una dote a la mujer. Dicha dote ingresaba en el ámbito patrimonial del marido o de su padre. No obstante, ante el paulatino debilitamiento de la patria potestas que hemos ya descrito, la dote fue entendiéndose como algo propio de la mujer, aunque siempre en el terreno de los principios y no en la legislación ${ }^{28}$. Por su parte, el varón romano no hacía aportaciones importantes al matrimonio. Sin embargo, incluso antes de Constantino, comenzó a introducirse la costumbre de que el marido hiciera también una donación nupcial significativa ${ }^{29}$. La transformación es impresionante, pues en vez de pasar la mujer del ámbito patrimonial de su padre al de su suegro, ahora marido y mujer generan, mediante estas donaciones nupciales, una esfera independiente y de carácter nuclear.

Esas donaciones fueron naturalmente vinculadas a la herencia, lo que no es de extrañar. Si los hijos tienen una expectativa reforzada respecto de la herencia de sus progenitores (la legítima), es fácil dar el paso de entender que las donaciones nupciales son un adelanto de esa herencia. De modo que al final de la Antigüedad, la familia entendida como una esfera jurídico patrimonial no nace ya con la muerte del padre como en la antigua Roma, sino con el matrimonio de los cónyuges. Y no solo eso, además las familias de origen distri-

\footnotetext{
25 En la ya citada Nov. 118. Se trata de una tendencia generalizada, no de una innovación justinianea. Entre los visigodos: $C E$. 336, también $L V$. 4.2.2 la herencia pasa a los hijos, luego a los ascendientes y por último los colaterales Véase Calabrús (1991) pp. 167 y ss.; Lalinde, (1962) pp. 113 -130; Braga Da Cruz (1953) pp. 769-830; Zeumer (1944) p. 287. Sucede también en Italia: Besta (1963) pp. 45 y ss.

26 CI. 6.61.1 (426 DC.)

27 Justiniano, en su Nov. 18, modifica el régimen hasta ahora esbozado salvando la validez del testamento que no respeta la parte legítima mediante el establecimiento de la actio ad implendam legitima. Su fin es que el perjudicado injustamente por un testamento pudiera reclamar dicha porción. A su vez incrementó la porción legítima de los hijos de un cuarto a un tercio de lo que les hubiera correspondido en la sucesión ab intestato, y si fueran cinco o más hijos, en la mitad del total del as hereditario. Entre los visigodos, con la ley Dum inlicita de Chindasvinto, se estableció una reserva en favor de los descendientes (LV.4.5.1)

28 Véase García Garrido (1958) pp. 19-26; García Garrido (1982) pp. 23-24 y 43-45; también TregGiari (1993) pp. 323-364

29 Sobre la donatio propter nuptias véase García Garrido (1982) pp. 150-162; Anne (1941); Vismara (2000) pp. 1-106; en Castilla durante el medioevo López Nevot (1998).
} 
buyen el patrimonio familiar en ese momento, adelantando así la herencia. El testamento casi desapareció del mundo altomedieval, en su lugar reinaron las donaciones en vida, normalmente destinadas a constituir una nueva familia ${ }^{30}$. Al recibir esa donación, el hijo y la hija debían considerarse propietarios y, por lo tanto, independientes; de ahí que durante la Edad Media se asocie intensamente emancipación y matrimonio ${ }^{31}$.

El matrimonio, pues, ya desde la Antigüedad tardía, concentraba a su alrededor la emancipación de los hijos, la creación de una esfera familiar de estructura nuclear y la distribución del patrimonio familiar. Sin duda se trataba del centro del mundo privado. Y esa esfera sobrevivía incluso a la muerte de uno de los cónyuges. En el mundo antiguo los hijos pertenecían al padre, pues él tenía el poder sobre ellos. Al morir el padre se emancipaban. En el mundo medieval la mujer viuda es continuadora de la familia nuclear, los hijos permanecen bajo su cuidado y ella debe administrar el patrimonio familiar hasta su emancipación que, como hemos dicho, normalmente se produce con el matrimonio o la mayoría de edad que les permite a los hijos reclamar el patrimonio del padre muerto ${ }^{32}$. Este es el ciclo de vida de la familia nuclear que se inaugura en esta época y que persiste, con las modificaciones que veremos más adelante, hasta hoy.

Todas estas normas que cambian en los albores de Occidente actúan, tal como decíamos al principio, a modo de válvulas antirretorno, pues poco a poco configuran un conjunto que se corresponde a la familia nuclear dentro del amplio conjunto de parientes. Un conjunto al que entran bienes, pero no marchan, salvo que la familia nuclear desaparezca por completo.

En suma, puede afirmarse que las normas válvula que permiten identificar a la familia nuclear como un subconjunto dentro del conjunto de parientes aparecieron a finales de la Antigüedad y principios de la Edad Media. Algunas de las principales son: 1) la emancipación por matrimonio que significa la salida del hijo o la hija del ámbito de la familia de origen y permite formar una nueva esfera, junto a su cónyuge y sus hijos, regida de manera relativamente independiente por ambos consortes; 2) la preferencia de los descendientes en la sucesión respaldada por la legítima, pues una vez han nacido los hijos, la devolución hereditaria a favor de los ascendientes queda cancelada. De este modo, por herencia, los bienes pueden entrar en la esfera de la familia nuclear formada por los hijos que han contraído matrimonio (y se han emancipado en virtud de la primera norma); pero si estos a su vez tienen hijos, ni esos bienes ni ningún otro puede salir de dicha esfera por derecho hereditario. Dichas salidas solo se producirán en favor de los hijos que hasta su emancipación forman parte de la familia nuclear. La única hipótesis de retorno de los bienes a las familias de origen es la disolución de la familia nuclear por la muerte de sus integrantes. 3) El cuidado personal de los hijos corresponde a ambos cónyuges y, a falta de uno, al cónyuge sobreviviente. De esta forma, la familia nuclear se perpetúa en el cónyuge viudo y sus hijos menores, por lo menos hasta que estos reciban la administración de los bienes que han heredado del cónyuge difunto. Este hecho normalmente coincidía con el matrimonio o la mayoría de

\footnotetext{
Vismara (1998) pp. 120 y ss.

1 Vial-Dumas (2014b) pp. 312-320

32 Dalla (1983); Vial-Dumas (2014b) pp. 316-318.
} 
edad. De este modo el cónyuge viudo se transformaba en propietario de una parte de los bienes de la familia nuclear, usufructuario de otra parte de dichos bienes y administrador de otros que pertenecían a los hijos ${ }^{33}$.

Estas tres normas básicas cierran el círculo o conjunto que denominamos familia nuclear. A través de estas normas podemos identificar que ha nacido, para el derecho, una esfera relativamente independiente e identificable dentro del conjunto de los parientes. Antes de que esto ocurriera, al menos desde una perspectiva jurídico patrimonial, era difícil identificarla pues estaba absorbida por la familia extensa basada en el poder del padre.

\section{LA FAMILIA NUCLEAR EN LA ÉPOCA DE LOS LINAJES}

La realidad antes descrita, en sus rasgos esenciales, no varió mucho durante los siglos posteriores, antes bien fue definiéndose ${ }^{34}$. Sin embargo, durante la baja Edad Media (s. $\mathrm{X}-\mathrm{XV}$ ) comienzan a formarse nuevas estructuras familiares y suprafamiliares que significaron una alteración de las reglas que definían la existencia y ciclos de la familia nuclear desde el punto de vista del derecho. Esta variación en el juego de las normas válvula, fue impulsado por el conocido fenómeno de los linajes que se presentó ya desde principios del segundo milenio. El proceso eclosionará, no obstante, entre el siglo XIV y XV y determinará la forma de las familias europeas hasta, al menos, el siglo XIX.

El fenómeno de reconcentración del poder político y económico que experimentara Europa desde el siglo X y su aceleración desde el siglo XIII, llevó a las grandes familias a evitar la división del patrimonio familiar entre los hijos, lo que hasta entonces era la regla. Durante el alto Medioevo, en la mayoría de las regiones de Europa, el patrimonio familiar se dividía entre todos los hijos, o al menos entre los hijos varones, en igualdad de condiciones ${ }^{35}$. Dicha división tenía lugar, como hemos ya mencionado, en el momento del matrimonio y en el momento de la muerte de los padres. Asimismo, el matrimonio o la mayoría de edad solía liberar al hijo de la potestad paterna.

No obstante, las reglas hasta entonces vigentes fueron modificadas en varios frentes y muchas de estas modificaciones vinieron de la mano de la recepción del derecho común y la recuperación de algunas de sus reglas referidas a la antigua familia romana. No porque el derecho común contuviera un modelo de familia distinto (contenía en realidad varios), sino porque las instituciones del derecho común daban forma a algunas de las pretensiones sociales de la época. De modo que dicho derecho no fue el impulsor de estos cambios, sino la herramienta que en algunos casos se utiliza para consolidarlos. De hecho, las normas de derecho común que no convienen a estos intereses son simplemente ignoradas. Así, por ejemplo, se modifican las normas de la emancipación recuperando el carácter perpetuo de la patria potestas, aunque solo en su contenido patrimonial; aquí se echa mano del derecho

33 Véase Guerra Medici (1986) pp. 250-261; Gacto (1975).

34 En la península Ibérica: Bermejo (1996) p. 688

35 En algunas regiones de Europa fue frecuente la exclusión de las mujeres de la herencia por medio de la dote. En Italia, por ejemplo, Cortese (1997) pp. 154-155; SKINer (2005) p. 163; LeVerotti (2007). En territorios de la península Ibérica la exclusión de las mujeres no es tan acusada, aunque para el siglo XIV también su práctica será habitual: LALINDE (1963) p. 236 y GÁmeZ (1998) p. 96. En otros territorios véase BROUGARD (2002) 
común $^{36}$. Al contrario, poco a poco la igualdad hereditaria de los hijos se ve mermada en favor de la institución de un heredero único, aunque el derecho común favorecía la igualdad. Esta institución, la del heredero único, a pesar de comenzar a ser justificada jurídica y moralmente desde el siglo XII, no se extendió masivamente sino hasta el siglo $\mathrm{XV}^{37}$. Por último, la viuda dejó de ser la continuadora de la familia nuclear, para convertirse en un actor más de las estrategias familiares que favorecieran la perpetuación del linaje ${ }^{38}$. Este es un tema que no podemos abordar aquí. Pero podemos decir que, entre otras novedades, esta nueva corriente social determinó no solo la aparición del heredero único, sino su evolución en formas sucesorias monolíticas como el mayorazgo o bien en estrategias para vincular los bienes al linaje, como los censos o los fideicomisos y sustituciones. Todas estas instituciones tendían a evitar la disgregación patrimonial del linaje ${ }^{39}$. Por ese motivo se trata de instituciones primordialmente usadas y justificadas para la nobleza y no tanto en otros estratos ${ }^{40}$.

Los linajes fueron verdaderos actores políticos y su existencia quedó materializada no solo en la acumulación de un gran patrimonio y poder político; también en símbolos y apellidos, en monasterios y fundaciones religiosas vinculadas a la familia, e incluso en elementos arquitectónicos urbanos (torres, barrios, lápidas, etc.) que sobreviven hasta hoy en muchas ciudades europeas. En medio de la acción política y económica de estos linajes, el matrimonio y la familia nuclear quedan ahogados en los intereses de subsistencia y ascenso social del grupo familiar extenso. A menudo es solo el hijo mayor el que puede casarse, en otras ocasiones, el resto de los hijos reciben un pequeño patrimonio en forma de dote o praemium emancipationis y son emancipados y desligados de la familia. Estos hijos forman familias nucleares, es decir esferas económicas relativamente autónomas formadas en el momento del matrimonio por el patrimonio de los cónyuges y los hijos. Estas familias, no obstante, a menudo son como satélites del patrimonio familiar principal en manos del padre y luego del hermano que lo herede indiviso. Por eso, el núcleo del linaje es más cercano a la estructura de la familia patriarcal romana, e incluso va más allá. La familia romana se dividía con la muerte del padre. Podíamos decir que allí terminaba su ciclo y se renovaba mediante la división del patrimonio. En otras palabras, se trata de una familia que acababa y nacía con la muerte. La familia nuclear, por su parte, se inaugura con el matrimonio, es entonces cuando la esfera patrimonial de los cónyuges comienza su vida autónoma. Los linajes, en cambio, generaron una familia que trasciende a la muerte, que se institucionaliza y cobra una personalidad económica y política que está por sobre los individuos que los componen. Por eso, todo es por el linaje y su subsistencia somete a las personas a un férreo control por parte de su administrador, el pater familias.

\footnotetext{
36 Véase Bellomo (1992) p. 65; Bellomo (1966) p. 31 y ss. y Torelli (1947) p. 54.

37 Clavero (1989) y Clavero (1993)

38 Sobre el fenómeno de nacimiento y consolidación de los linajes véase entre muchos otros: CAMMAROSAno (1979); Del Treppo (1977); Violante (1984) pp. 19-82; Pastor (1993); Di Renzo Villata (1995) pp. 497-498. Bellomo (1966) y Bellomo (1992); Leverotti (2005) pp. 101 y ss; Duby y Le Goff (1984); Duby (1988); Heers (1978); Klapisch-Zuber (1995); To Figueras (1997); Romano (1994) y Clavero (1989).

39 Clavero (1989), Clavero (1993), Di Renzo Villata (1995) pp. 497-498; Bermejo (2009) pp. 549 y ss; Romano (1994) en especial pp. 49 y ss; To Figueras (1993) y To Figueras (1997);

40 Clavero (1989), una visión general en las pp. 435-473
} 
Pero no solo eso. Los linajes también generaron o coadyuvaron a configurar la estructura política de la sociedad del Antiguo Régimen. La tendencia a la concentración del poder llevó al estancamiento político y económico contra el que se pronunciaran tantos filósofos ilustrados y contra el cual se levantó la revolución burguesa. La animadversión por los monopolios, la fascinación por la circulación de la propiedad, las legítimas, la abolición de instituciones como los mayorazgos fueron como torpedos lanzados contra la línea de flotación del Antiguo Régimen; pues, en definitiva, aquella sociedad en buena medida se sostenía en las normas de derecho de familia y sucesiones que serán modificadas. La nueva familia, que rompe con las estructuras de linaje, quedará plasmada en los códigos de derecho privado del siglo XIX.

\section{LA FAMILIA CODIFICADA}

Un testimonio muy conocido de la nueva visión de la familia que enarboló la Ilustración es el de Beccaría: "si la sociedad está constituida por familias, habrá veinte mil hombres y ochenta mil esclavos; si lo está por hombres, no habrá esclavo alguno y sí cien mil ciudadanos. (...). Cuando la república es de hombres, la familia no es una subordinación de mando, sino de contrato, y los hijos, al tiempo que la edad los saca de la dependencia de naturaleza, por su flaqueza y necesidad de educación y defensa, vienen a ser miembros libres de la ciudad, y se sujetan al cabeza de familia por participar sus ventajas, como los hombres libres en las grandes sociedades. (...) no subsiste otro vínculo de mando que el sacro e inviolable de suministrarse recíprocamente los socorros necesarios, y el de la gratitud por los beneficios recibidos" ${ }^{41}$. Igual que él, muchos otros pensadores ilustrados estimaron necesario acabar con ciertas estructuras sociales y del derecho de familia y sucesiones que impedían lo que debía ser, según el pensamiento liberal, el natural desarrollo de las sociedades y los individuos. No solo había que medrar los poderes colectivos como gremios, ciudades o señoríos; también había que destruir la herencia y las estructuras familiares que superaran aquello que, tal como ellos entendieron, constituía la familia natural ${ }^{42}$. Esa familia natural estaría desprovista de un papel político y no estaría dotada de artificios jurídicos que tendieran a atrapar los bienes y ligarlos al linaje. La familia natural era aquella formada por padre madre e hijos (y algún que otro allegado) cuya esfera de propiedad se formaba con el matrimonio y se dividía al momento de la muerte por partes iguales entre los hijos (aunque cupiese la posibilidad de mejorar a alguno). Así, el matrimonio, en muchos de los

41 BeCCARIA. En el mismo pasaje afirma "El espíritu de familia es un espíritu de detalle y limitado a los hechos pequeños. El espíritu regulador de las repúblicas, dueño de los principios generales de los hechos y los distribuye en las clases principales e importantes al bien de la mayor parte".

42 Rousseau comentaba sobre el particular: "La sociedad más antigua de todas, y la única natural, es la de una familia; y aún en esta sociedad los hijos solo perseveran unidos a su padre todo el tiempo que le necesitan para su conservación. Desde el momento en que cesa esta necesidad, el vínculo natural se disuelve. [...] Es pues la familia, si así se quiere, el primer modelo de las sociedades políticas: el jefe es la imagen del padre y el pueblo es la imagen de los hijos; y habiendo nacido todos iguales y libres, solo enajenan su libertad por su utilidad". El contrato social, Libro I Cap. II. En general la doctrina de los Philosophes fue todavía más allá de lo que iría la codificación, no obstante, en lo que a aquí nos compete, sentó las bases del tratamiento que los códigos harán del derecho de las personas y de familia. Rousseau (1836) pp. 5. 
VIAL-Dumas, Manuel " "La familia nuclear ante el derecho. Una retrospectiva de su formación y definición..."

códigos decimonónicos, inauguraba algún tipo de sociedad o comunidad entre los cónyuges, sea de gananciales, universal o de otro tipo, y generaba una expectativa respecto de dicho patrimonio en favor los hijos; no obstante, ahí acababa la extensión patrimonial de la familia. Asimismo, el matrimonio natural pretendía sustraer del control eclesiástico la institución y en cambio convertirla en un contrato civil ${ }^{43}$. La familia natural, en fin, sería una institución perteneciente totalmente al mundo privado que nacía en ese momento. Aún así, el matrimonio no dejó de ser la clave de las alianzas entre familias, sin embargo, poco a poco su importancia irá disminuyendo en el ámbito patrimonial y sus funciones podrán ser, como veremos, reemplazadas.

Ya desde el siglo XVIII la afinidad emocional cobra una renovada relevancia entre las variables que se tenían en cuenta para concertar un matrimonio. Evidentemente, como aclara Coontz, este no es un cambio repentino, la unión matrimonial definida primordialmente por cuestiones emocionales y no tanto por intereses sociales o económicos no aparece con claridad hasta mucho tiempo después. No obstante, es cierto que en esta época se pone en valor el amor conyugal frente a la disciplina familiar impuesta por las necesidades patrimoniales de la familia ${ }^{44}$. Solo entonces, en el marco del liberalismo decimonónico, el matrimonio pudo comenzar a abandonarse al amor romántico. Sin duda un cambio de esa naturaleza era viable únicamente en una sociedad en que el matrimonio se restringía poco a poco a lo privado, a la esfera individual, y dejaba de ser un asunto político.

En efecto, el liberalismo que inspiró los códigos modernos se enfrentó, como una de sus principales preocupaciones, al fenómeno nobiliario que impedía la circulación de los bienes y del poder político y lo concentraba en pocas manos. Estas instituciones afectaban a la burguesía que, también poderosa en el ámbito económico, quedaba relativamente excluida de las relaciones de poder. De ahí que la burguesía librara la misma batalla que desarrolló en el ámbito público con la bandera del constitucionalismo, en el ámbito privado con la herramienta de la codificación ${ }^{45}$. Esta es una historia conocida. Las relaciones jurídicas en ese nuevo mundo liberal se conciben primordialmente como relaciones individuales y la realidad colectiva de la familia nuclear o extensa o patriarcal queda opacada por dicho principio. De esa forma, la libre circulación de los bienes consagrada como valor en todos los códigos decimonónicos tenía en el derecho de familia una de sus manifestaciones más claras. Los censos, sustituciones fideicomisarias, pactos sucesorios y toda fórmula para evitar la división de la herencia fueron vistas con desconfianza por el legislador liberal y, si no abolidas, al menos fueron restringidas en su aplicación. Al contrario, la codificación puso el acento en la familia nuclear retomando y reforzando las normas válvula que permiten su

\footnotetext{
43 Véase Gaudemet (1993) pp. 449 y ss. Aún así, muchos códigos beben del derecho canónico en lo referente a la regulación del derecho de familia, sea de forma manifiesta o no. En el caso particular del Código de Bello es interesante SALINAS (2006).

44 Coontz (2006) pp. 185-204 una revisión de la bibliografía y el desarrollo de la misma en Europa e Iberoamérica en CHACÓN (2003).

45 Para el modelo de relaciones privadas que proponen la mayoría de los códigos decimonónicos y la filosofía que le sirve de antecedente la bibliografía es inabarcable, para este fenómeno referido en particular al derecho de personas y familia véase una exposición general en Di Renzo Villata (1995) pp. 470-484 y 505-527.
} 
existencia y que ya estaban presentes en siglos anteriores y también, en ese mismo tiempo, entre muchas de las familias que no formaban parte de los estamentos privilegiados ${ }^{46}$.

La familia de la codificación no alcanzó las fronteras propuestas por muchos de los filósofos ilustrados o por el legislador revolucionario en el caso francés; al contrario, en muchos sentidos el código de Napoleón es restaurador de valores tradicionales ${ }^{47}$. Eso no hace menos cierto, no obstante, que en lo que a la familia nuclear respecta, el código francés y la mayoría de los códigos (que por lo demás no sufrieron la violenta fluctuación que significó, en el caso del primero, estar precedido por un periodo revolucionario) recuperaron la vigencia o reposicionaron aquellas normas que hemos caracterizado como válvulas antirretorno. Son estas normas las que permiten la existencia de la familia nuclear en cuanto esfera patrimonial. Una de esas recuperaciones o reposicionamientos se produce en el caso de las legítimas. En buena parte del ámbito hispánico, los códigos optaron por limitar la libertad de disposición del padre mediante dicha institución ${ }^{48}$. Como ya hemos señalado, las legítimas tienen larga data. Fueron recogidas en la obra de Justiniano y convivieron con las reservas hereditarias en territorios de influencia germánica ${ }^{49}$. Sin embargo, sobre todo a partir del siglo XIII, como señalamos arriba, la efectividad de estas limitaciones se relativiza en favor de prácticas tendentes a la indivisión de la herencia. Este objetivo se conseguía sea a través de instituciones hereditarias o de estrategias relacionadas con el matrimonio; por ejemplo, el celibato forzoso de algunos hijos para evitar la división del patrimonio familiar mediante las donaciones matrimoniales de rigor $^{50}$. En esta época, en cambio, la legítima recupera su vigencia y se impone sin mayores excepciones dejando al padre solo una cuota de libre disposición. No es que antes los padres pudieran disponer con toda libertad de la herencia, muchas veces, producto de instituciones hereditarias como el mayorazgo o los fideicomisos, la realidad era la contraria. En otras palabras, el padre no podía disponer ni dividir la herencia familiar, sino simplemente traspasar el patrimonio del linaje de generación en generación intentando acrecentarlo.

El derecho de la codificación, al revés, obliga a dividir y al hacerlo, aporta también unas reglas de mínimos que encuentra en la tradición medieval; en el caso del mundo hispánico, esas reglas provienen sobre todo del derecho castellano ${ }^{51}$. La obligación de dividir la herencia entre los hijos despoja a las familias de una de las estrategias clave para mantener

\footnotetext{
46 Una visión general en Vismara (1978) pp. 23 y ss. También Bellomo (1970) pp. 69 y ss.; Di Renzo Villata (1995) pp. 470 y ss.

47 Halperin (1992) pp. 276-277

48 En el caso hispánico la limitación es importante. El proyecto de Código Civil Español de 1851 limitaba a un tercio la facultad de disposición del padre en el caso de haber un hijo y a un quinto si eran dos o más (art.642), El código de Bello otorgaba al causante la cuota de libre disposición de un cuarto de la herencia y otra cuarta parte para mejorar a ciertos parientes (art. 1184). Véase la discusión sobre esta cuestión en el marco de la codificación española en Pérez (2005); también Pacheco (2012)

49 La evolución en Francia hasta la codificación en Peguera (2009) pp. 259 y ss.

50 Desde el alto Medioevo hasta la codificación, las transferencias patrimoniales que se hacen con ocasión del matrimonio están conceptualmente muy ligadas a la herencia, VIAL-Dumas (2017).

51 Bello, en principio partidario de una mayor libertad testamentaria, se aparta en alguna medida de la tradición castellana medieval e intenta acercarse, al menos en sus proyectos, a la tradición romana. García Goyena recoge en cambio un sistema de legítimas muy similar al contenido en la tradición foral, SALINAS (1977)
} 
el estatus económico y político, además pone en circulación bienes que antes eran heredados en masa y no podían ser divididos ni enajenados.

Otra recuperación de las normas válvula es la emancipación, aunque en este caso hay importantes modificaciones. La emancipación ya no está asociada con la misma fuerza al matrimonio, sino a una edad determinada. El criterio de la edad no era desconocido en el derecho anterior, de hecho, muchas veces actuaba como un criterio alternativo al del matrimonio ${ }^{52}$. Esto sucedía, por ejemplo, cuando los hijos, llegada una determinada edad, podían reclamar al progenitor sobreviviente la herencia del padre o la madre premuerta ${ }^{53}$. Sin embargo, dicho criterio rara vez había actuado de forma autónoma y, sobre todo, se entendía que actuaba cuando no había operado la emancipación por matrimonio o economía separada. En el derecho de la codificación en cambio, la edad es criterio suficiente y único para la emancipación, aunque, en la práctica, incluso hasta épocas muy recientes, matrimonio y edad siguieron actuando como dos criterios complementarios. De esta forma, tal como se desarticula la facultad de disposición que el padre de familia podía ejercitar mediante el testamento, se restringe también su poder en vida a través de la limitación legal y clara de la patria potestas. Se trataba en definitiva de acometer modificaciones similares a las que acontecían en el ámbito público: el poder absoluto del rey mutarlo en un poder limitado por una constitución; en el caso de la familia, de monarquía convertirla también en una sociedad basada en un pacto, uno que se suscriba además voluntariamente pues el consenso de los padres poco a poco deja de ser un elemento jurídicamente relevante al momento de la elección del cónyuge ${ }^{54}$. Evidentemente, ni en el ámbito público ni en el privado la filosofía que inspiró la revolución logró todos sus cometidos, sin embargo, se sentaron importantes bases para el desarrollo posterior.

Otro rescate es también el del papel del cónyuge viudo como administrador de la familia nuclear hasta el momento de la emancipación de los hijos. Esto es así en la medida que administra el patrimonio de los hijos menores de edad y también el patrimonio que le corresponde como resultado de la liquidación de la sociedad conyugal (si es que existía) o alguna cuota como usufructuario o bien como heredero. En el derecho tradicional, desde la Antigüedad tardía, la figura del cónyuge viudo tiene una importancia extraordinaria. Cuando la estructura de la familia patriarcal romana entró en decadencia, los bienes del matrimonio quedaron en manos del cónyuge viudo; antes, la viuda normalmente o se mantenía en la familia del padre del marido o volvía a su hogar paterno o se incorporaba en el de alguno de sus hijos. Los hijos pertenecían al padre y a su estirpe. Como se ha dicho, en el derecho tradoantiguo y altomedieval, en cambio, los hijos pertenecen a ambos cónyuges y la patria potestad suele ejercerse incluso de manera conjunta ${ }^{55}$. Pero en la baja Edad Media y en la sociedad de la primera modernidad, al menos en el ámbito aristocrático, la mujer viuda tiene otra vez un difícil encaje. A menudo es muy complicado devolver una dote y

\footnotetext{
52 Vial-Dumas (2014b) pp. 316-321

53 Ver No 32

54 En Francia, en plena revolución, en virtud de la ley del 22/25 de septiembre de 1792, se hace innecesario el consentimiento de los familiares para el matrimonio válido. Aunque luego Napoleón restaurará parcialmente dicha autoridad, a la larga esta será la concepción que acabará imponiéndose en los códigos.

55 Vial-Dumas (2014b) pp. 314-316
} 
la propiedad de la familia se encuentra en una buena parte indivisa; de modo que muchas veces la viuda permanece en la familia del marido, pero sus facultades como administradora disminuyen a favor de las estrategias del linaje ${ }^{56}$.

No obstante, para la mayoría de las familias, las no comprometidas en el juego de los linajes, el cónyuge viudo es continuador de la familia nuclear en cuanto rector de su patrimonio como conjunto. Eso no obsta a que siempre se reconocieran distintas calidades respecto de los múltiples bienes que lo componían, como dueño, usufructuario o mero administrador. Para la familia de los códigos el cónyuge tiene un papel similar. El cuidado de los hijos a cargo del cónyuge sobreviviente sigue alargando el ciclo vital de la familia nuclear hasta la emancipación de los mismos, aun cuando falte uno de los codirectores de la unidad conyugal ${ }^{57}$. Por su parte, el derecho sigue prefiriendo a los descendientes al momento de la distribución de los bienes que están dentro de la esfera de la familia nuclear, lo que evita su salida en el evento de la muerte de alguno de los cónyuges.

Las normas válvula que sí sufren alteraciones mayores son algunas de las relacionadas con las nupcias. En el derecho tradicional, la familia tenía como centro el momento del matrimonio en varios sentidos. Como hemos señalado, el matrimonio creaba normalmente una esfera patrimonial diferenciada que se veía consolidada con el nacimiento de los hijos. El matrimonio también desencadenaba normalmente la emancipación de los hijos. Por último, el matrimonio marcaba el momento crucial de la distribución del patrimonio familiar (mucho más que la herencia, esto es sobre todo cierto durante la Edad Media) ${ }^{58}$. En el derecho de la codificación y en sus antecedentes en el derecho anterior, el matrimonio mantiene su lugar central en el mundo privado. Esto es así sobre todo en lo que respecta al primero de los efectos que mencionaba, es decir, a que el matrimonio constituye una esfera jurídico-patrimonial diferenciada que se consolida con el nacimiento de los hijos, pues desde ese nacimiento opera la norma válvula que invierte todos los cursos hereditarios en su favor. Sin embargo, el matrimonio ya no marca ni el momento de la emancipación, ni el momento de la distribución del patrimonio familiar. El ciclo de vida de la familia nuclear del derecho tradicional podía describirse en función del matrimonio; este crea la esfera de la familia nuclear y esa esfera se consolida con el nacimiento de los hijos. Con el matrimonio los hijos salen de dicha esfera que, en muchas ocasiones, se divide al menos parcialmente para dar nacimiento a la nueva familia nuclear. La familia de la codificación nace a la vida con el matrimonio y se consolida con el nacimiento de los hijos, sin embargo, los hijos salen de dicha familia sin que se divida el conjunto, pues dicha división no acaece sino hasta el momento de la muerte de los padres. A cambio, la sociedad contemporánea creó mecanismos, como la emancipación por edad y el deber de educar y establecer a los hijos (que se consideraron deberes impuestos por naturaleza), que actúan como sustitutos de las

\footnotetext{
56 Di Renzo Villata (1995) p. 466; Bellomo (1970) pp. 37 y ss.

57 Los códigos modernos al reconocer al cónyuge sobreviviente la administración o el usufructo de los bienes de los hijos, preserva la unidad de la familia nuclear hasta que estos sean mayores de edad.

58 Aunque en época moderna y contemporánea se sigue utilizando sistemas de distribución patrimonial mediante pactos matrimoniales o donaciones matrimoniales. El caso paradigmático es la institución del heredamiento catalán. Véase: To Figueras (1997); Lalinde (1963); Pérez (2005) pp. 331-367; Montagut y Mikes (2016) pp. 21-49.
} 
donaciones que, en el derecho tradicional, las familias de origen hacían a los hijos para procurar la constitución de su familia.

En efecto, el cambio de funciones del matrimonio tenía que ir de la mano del reemplazo del mecanismo de las donaciones nupciales. La creación de una esfera jurídicopatrimonial autónoma se sigue produciendo, pero el contenido de dicha esfera será ahora el fruto de las rentas o el trabajo asalariado de uno o de ambos cónyuges. De esa manera se puede dotar de sustancia patrimonial a la familia nuclear sin proceder a la división del patrimonio de las familias de origen. El matrimonio deja de marcar ese momento de división que queda otra vez pospuesto hasta la muerte de los padres. Evidentemente este cambio no se da de un día para otro. Las donaciones nupciales, en particular la dote, más que abolida es una institución que cayó paulatinamente en desuso. Normalmente cuando se habla de familia moderna y su modelo primordialmente nuclear, se piensa en este fenómeno, sin embargo, esto no es más que una alteración en las normas válvula que, como hemos señalado, tienen origen y aplicación desde la Antigüedad tardía. Es cierto que la paulatina desaparición de las donaciones nupciales y la pérdida del carácter estratégico del matrimonio sí son una novedad en la historia occidental. Sin embargo, no se trata de un cambio radical, sino simplemente de la refacción de un compuesto de normas que configuran jurídicamente la familia nuclear y que ya venía funcionando desde siglos. Es indudable, no obstante, que estos cambios abren la puerta a la crisis actual del matrimonio. No me refiero a una crisis moral, sino a la crisis de la institución jurídica y su funcionalidad económica como centro de creación y división del patrimonio familiar. Despojado el matrimonio de esta función, también su importancia social decae y puede ser reemplazado, modificado y desplazado hasta convertirse en una institución de importancia marginal, como parece ser hoy.

\section{CONCLUSIONES}

La familia ante el derecho puede ser retratada como una esfera jurídico-patrimonial. Dicha esfera es reflejo de la realidad moral de la familia, una realidad determinada principalmente por los vínculos que produce el parentesco y el matrimonio (y también, en cierta medida, sus substitutos). Una ventaja del análisis jurídico patrimonial es que permite analizar las estructuras familiares a partir de las relaciones jurídicas que unen a determinadas personas y los cambios que en estas se producen en la medida que cambian los estados civiles de las mismas. Otra ventaja es que permite caracterizar las estructuras familiares como un juego de conjuntos y subconjuntos determinados por esas relaciones jurídicas. El grupo más amplio que puede identificarse como familia es el conjunto relativamente indeterminado de los parientes. El más pequeño es la familia nuclear. Este último conjunto puede ser identificado a través de criterios adicionales que van más allá de las simples relaciones de parentesco o afinidad. Se trata de normas que permiten dibujar con cierta claridad las fronteras de la familia nuclear. Dichas normas actúan como válvulas antirretorno, en la medida que los bienes que entran a un determinado subconjunto de parientes no pueden luego salir del mismo; al contrario, el derecho los destina en beneficio de los miembros de ese subconjunto, aún en contra de la voluntad de sus rectores. 
La evolución histórica de Occidente nos muestra cuáles son esas normas en el contexto de su nacimiento. La Antigüedad tardía vio formarse todas las normas válvula que configuraron la familia nuclear occidental en el derecho. Se trata básicamente de a) la emancipación por matrimonio o mayoría de edad que permite la fundación de una esfera patrimonial autónoma, b) la preferencia de los descendientes en el ámbito hereditario, c) la división forzada de la herencia a través de la institución de la legítima, y d) que el cuidado de los hijos y la dirección de la familia recaiga en ambos cónyuges, de manera que el viudo o viuda mantiene la estructura de la familia nuclear hasta, al menos, la emancipación de los hijos. Desde entonces han estado, al menos en lo sustancial, vigentes ininterrumpidamente, aunque no en todos los medios sociales. En efecto, al final de la Edad Media y en la primera Modernidad, al interior los círculos nobiliarios se articularon estrategias que tendían a concentrar el patrimonio de una entidad suprafamiliar como fueron los linajes. Sin embargo, el ideario ilustrado reorientó y recuperó algunas de estas normas válvula, aunque desde una perspectiva individualista. Aun así, en lo esencial, la estructura inaugurada en el nacimiento de Occidente sobrevivió en los códigos decimonónicos.

La familia contemporánea, igual que la familia del derecho medieval y moderno, es primordialmente una familia nuclear, aunque su delimitación como conjunto sea más compleja. En efecto, el ciclo de vida de la familia nuclear se ha modificado ligeramente en la medida que las normas válvula también han sufrido modificaciones. Las principales tienen que ver con la función económica del matrimonio. En efecto, la emancipación ha dejado de estar asociada a las nupcias, tanto en el plano jurídico como en el social, y el matrimonio ha dejado de ser identificado con un momento importante de distribución del patrimonio familiar, como era en el derecho tradicional. Es evidente que el debilitamiento social de la institución del matrimonio lo ha desplazado del centro del mundo jurídico privado. A cambio, el deber de educar a los hijos y el trabajo asalariado han proporcionado medios para la emancipación efectiva de estos. De esta manera, el patrimonio familiar se distribuye solo con la muerte de los progenitores y el matrimonio deja de ser fundamental en la configuración de la familia nuclear. Ese hecho, constatable fácilmente en el ámbito jurídico patrimonial a través de las modificaciones de las normas válvula desde que dichos códigos comenzaron a ser dictados, abrió la puerta al matrimonio por amor y, al mismo tiempo, lo condenó a la intrascendencia patrimonial. Como resultado de esta evolución, el matrimonio se ha desdibujado y ha podido ser, por una parte, asimilado a otras uniones civiles o de hecho y, por la otra, puede dejar de ser controlado por el estado. En efecto, la legislación estatal entró a regular el matrimonio por su capital importancia para la reestructuración social que en el siglo XVIII y XIX se proponía; la actual intrascendencia, en cambio, abre la puerta a que el matrimonio sea abandonado por el estado y se reconvierta en una institución gobernada libremente por los grupos religiosos o ideológicos que conforman la sociedad civil. Está por ver si es ese u otro el camino que tiene por delante la institución matrimonial. 


\section{BIBLIOGRAFÍA CITADA}

Amunátegui, Carlos (2009): Origen de los poderes del paterfamilias. El pater familias y la Patria Potestas (Madrid, Dykinson).

ANne, Lucien (1941): Les rites des fiançailles et LA DONATION POUR CAUSE DE MARIAGE SOUS le Bas-Empire (Louvain, Desclée de Brouwer).

Bartolus de Saxoferrato (1555): Commentaria in primam infortiati partem (Lugduni)

BeCCARIA, Cesare (2015): Tratado de los delitos y de las penas (Madrid, U. Carlos III).

Bellomo, Manlio (1966): Profili della famiglia italiana nell'età dei Comuni (Catania, Giannotta).

Bellomo, Manlio (1992): "La struttura patrimoniale della famiglia italiana nel Tardo Medioevo" en Bonfield, Lloyd (ed.), Marriage, Property, and Succession (Berlín, Duncker \& Humblot) pp. 53-69.

Bellomo, Manlio (1970): La condizione giuridica della donna in Italia (Torino, Eri).

Bermejo, Manuel (1996): Parentesco, matrimonio, propiedad y herencia en la Castilla altomedieval (Madrid, U. Carlos III).

Bermejo, Manuel (2009): Entre ordenamientos y códigos. Legislación y doctrina sobre la familia a partir de las Leyes de Toro (Madrid, Dykinson).

Besta, Enrico (1963): Le Successioni nella storia del diritto italiano (Milano, Giuffrè).

Bonnassie, Pierre (1979): La Catalogne du milieu du Xe a la fin du XIe siècle (Toulouse Pub. de l'Univ. de Toulouse-Le Mirail).

Bougard, François, Feller, Laurent y Le JAN, Régine (2002): Dots et dounaires dans le haut Moyen Âge (Roma, École française de Rome).

Braga Da Cruz, Guilherme (1953): "A sucessao legítima no Código Euriciano”, AHDE, 23: pp. 769-830.

CALABRÚs, Juan (1991): Las relaciones paterno-filiales en la legislación visigoda (Granada, Ins. de his. del derecho, U. de Granada)

Cammarosano, Paolo (1979): "La nobiltà del Senese dal secolo VIII agli inizi del secolo XII”, Bullettino senese di storia patria, 86: pp. 7-48.

CApogrossi, Luigi (2010): "La famiglia romana, la sua storia e la sua storiografia", Mélanges de l'École française de Rome - Antiquité 122-1: pp. 147-174.

Chacón, Francisco; Irigoyen, Antonio; De Mesquita, Eni y Lozano, Teresa (2003): Sin distancias. Familia y tendencias historiográficas en el siglo XX (Murcia, U. de Murcia).

Clavero, Bartolomé (1989): Mayorazgo (Madrid, Siglo XXI).

Clavero, Bartolomé (1993): "Beati Dictum, Derecho de Linaje, Economía de Familia y Cultura de Orden”, AHDE, 63: pp. 7-148.

Coontz, Stephanie (2006): Historia del matrimonio (Trad. Alcira Bixio, Barcelona, Gedisa).

Coulanges, Fustel de (1864): La cité Antique (París, Hachette)

Cortese, Ennio (1997): Il diritto nella storia medievale, Vol. I (Roma, Il Cigno Galileo Galilei, primera ed., seg. reimpresión).

Dalla, Danilo (1983): Praemium emancipationis (Milan, Giuffrè). 
Del Trepro, Mario (1977): "La nobiltà dalla memoria lunga: evoluzione del ceto dirigente di Amalfi dal IX al XIV secolo", en RossetTI, Gabriella (edit.), Forme di potere e struttura sociale in Italia nel medioevo (Bologna, Il Mulino) pp. 305-319.

Di Renzo Villata, Gigliola (1995): "Persone e famiglia nel diritto medievale e moderno", en Digesto IV, Discipline privatistiche (Turin, Utet) pp. 457-527.

DubY, Georges (1988): “Il matrimonio nella società dell'Alto Medioevo" en Duby, Georges, Medioevo maschio: amore e matrimonio (Trad. Maria Garin, Roma, Laterza, primera edición) pp. 5-25.

Duby, Georges, y Le Goff, Jacques (1984): Famiglia e parentela nell'Italia medievale, (Bologna, Il Mulino).

FAYER, Carla (1994): La familia romana. Aspetti giuridici e antiquari (Rome, L'Erma di Bretschneider)

Fischer Drew, Katherine (1988): Law and Society in Early Medieval Europe (London, Variorum Reprints).

Franciosi, Gennaro (2003): La famiglia romana: società e diritto (Torino, Giappichelli).

Gacto, Enrique (1975): La condición jurídica del cónyuge viudo en el derecho visigodo y los fueros de León y Castilla (Sevilla, Public. de la U. de Sevilla)

Gámez Montalvo, Ma Francisca (1998): Régimen jurídico de la mujer en la familia castellana medieval (Granada, Comares).

GarCía GaRrido, Manuel (1982): El patrimonio de la mujer casada en el derecho civil. I- La tradición romanistica (Barcelona, Ceac).

García Garrido, Manuel (1958): Ius Uxorium (Roma,Madrid, CESIC).

García Garrido, Manuel (1959): "El régimen jurídico del patrimonio uxorio en el derecho romano-visigótico”, AHDE, 29: pp. 389-446.

Gardner, Jane (1988): Family and Familia in Roman Law and Life (New York, Oxford University Press).

Gaudemet Jean (1993): El matrimonio en Occidente (Trad. María Barberán y Florentino Trapero, Madrid, Taurus).

Guerra Medici, Ma Teresa (1986): I Diritti delle donne nella società altomedievale (Napoli, Ed. scientifiche italiane).

Guichard, Pierre (1988): "La Europa bárbara” en Burguière, André; Zonabend Francoise; Klapisch-Zuber, Christine; Segalen Martine et al. (edit.), Historia de la familia, Vol. I (Madrid, Alianza) pp. 287-342.

Guichard, Pierre (1979): "De l'Antiquité au Moyen Age: Famille large et famille étroite”, Cahiers d'Histoire, 24: pp. 45-60.

Gutiérrez, Cándida (2006): “La institución de la familia en Roma”, en CatalÁ, Santiago (cord.) Evolución del derecho de familia en Occidente (Cuenca, U. Castilla-La Mancha) pp. 11-26.

Harris, Marvin. (1984). Introducción a la Antropología General (Trad. Juan Sánchez Fernández, Madrid. Alianza Editorial, 5a ed.).

Heers, Jacques (1978): El clan familiar en la Edad Media (trad. C. Escardó y R. Ortuño, Barcelona, Labor).

Herlihy, David (1985): Medieval Households (Cambridge, Harvard Univ. Press). 
VIAL-Dumas, Manuel — "La familia nuclear ante el derecho. Una retrospectiva de su formación y definición..."

Herrera, Héctor (1977): “Res Privata-Res Publica-Imperium”, en VV.AA., Semanas de Estudios Romanos I (Valparaíso, Ed. Univ. de Valparaíso) pp. 128-136.

Halpérin, Jean-Louis (1992): L'Impossible Code Civil (París, Presses Univ. de France).

Kaplan, Michel (1992): Les Hommes et la terre à Byzance du VIe au XIe siècle (París, Publications de la Sorbonne).

KInG, Paul (1981): Derecho y sociedad en el reino visigodo (trad. M. Rodríguez Alonso, Madrid, Alianza Editorial).

Klapisch-Zuber, Christine (1995): "Relazioni di parentela e vita politica a Firenze nel XIV secolo”, en Kertzer, David y SAlLer, Richard (eds.), La famiglia in Italia dall'antichità al XX secolo (Firenze, Le Lettere) pp. 233-254.

LaIou, Angeliki (2009): "Family Structure and the Transmissión of Property" en Haldon, John (ed.), The Social History of Byzantium (Wiley-Blackwell, Chichester) pp. 51-75.

LaLinde, Jesús (1962): "La sucesión filial en el derecho visigodo", $A H D E$, 32: pp. 113-130.

LaLinde, Jesús (1963): "Los pactos matrimoniales catalanes”, AHDE, 33: pp. 221-246.

LeVerotTi, Franca (2005): Famiglia e Instituzioni nel Medioevo italiano (Roma, Carocci).

Leverotti, Franca (2007): “Uomini e donne di fronte all'eredità. Il caso italiano" en VvaA. Familia y Sociedad en la Edad Media (siglos XII-XV) (Zaragoza, U. de Zaragoza) pp. 39-52.

Lévi-Strauss, Claude (1982): "La familia”. En Lévi-Strauss, Claude; Spiro, Melford y Gough, Kathleen (eds.), Polémica sobre el origen y la universalidad de la familia (Barcelona, Anagrama, $3^{\mathrm{a}}$ ed.) pp. 7-49.

López Nevot, José Antonio (1998): La aportación marital en la Historia del Derecho medieval (Almería, U. de Almería).

Montagut, Tomàs de y Mikes, Tünde (2016): “The Catalan Sagrada Família: Law and Family in Medieval and Modern Catalonia” en Di Renzo Vilata, Gigliola (ed): Family Law and Society in Europe from the Middle Ages to the Contemporary Era (Switzerland, Springer) pp. 21-49.

Murdock, George (1949): Social Structure (New York, Macmillan).

Pacheco, Francisco (2012) "Derecho histórico y Codificación. El derecho sucesorio", AHDE 82: pp. 113-147.

PASTOR, Reyna (1993): Resistencias y luchas campesinas, en la época de crecimiento y consolidación de la formación feudal, siglos X-XIII (Madrid, Siglo XXI).

VeYne, Paul (1978): "La famille et l'amour sous le Haut-Empire romain”, Annales Économies, Sociétés, Civilisations, 33: pp. 35-63.

Peguera, Marta (2009): Aux origines de la réserve héréditaire du Code civil: la légitime en pays de coutumes (Aix-en-Provence, Presses universitaires d'Aix-Marseille).

Pérez Collados, José María (2005): "El derecho catalán de sucesiones en vísperas de la codificación”, $A H D E, 75:$ pp. 331-367.

Romano, Andrea (1994): Famiglia, successioni e patrimonio familiare nell'Italia medievale e moderna (Torino, Giappichelli).

Ruiz Domenec, José (1975): "Las estructuras familiares catalanas en la Alta Edad Media" Cuadernos de arqueología e historia de la ciudad, 16: pp. 69-123.

SALinas, Carlos (1977): "Notas sobre los orígenes de la cuarta de mejoras en nuestra legislación civil”, REHJ,: pp. 143-157. 
Salinas, Carlos (2006): El influjo del Derecho Canónico en el Código Civil de la República de Chile, (Valparaíso, Ediciones Universitarias de Valparaíso).

Saller, Richard (1997): Patriarchy, Property and Death in Roman Family (Cambridge, Cambridge University Press).

Saller, Richard (1984): "Familia, Domus and the Roman Conception of the family", Phoenix, 38, No 4: pp. 336-355.

SEgalen, Martin (1981) Sociologie de la famille (París, Armand Colin).

SkInner, Patricia (2005): Le donne nell'Italia medievale, Secoli VI-XIII (trad. G. Federici, Roma, Viella).

Thomas, Yan (1990): "La divisione dei sessi nel diritto romano", en SchmitT-Pantel, Pauline (ed.), Storia delle donne, I. L'Antichità (Rome-Bari: Laterza) pp. 103-178.

Thomas, Yan (1988): "Roma: padres ciudadanos y ciudad de los padres (siglo II a.C.-siglo II d.C.)” en Burguiere, André [et al.] (eds.), Historia de la familia, Tomo I, (Madrid, Alianza) pp. 203-240.

To Figueras, Lluís (1993): “Señorío y familia: los orígenes del hereu catalán”, Studia Histórica - Historia Medieval, 11: pp. 57-79.

To Figueras, Lluís (1997): Familia i hereu a la Catalunya nord-oriental (Barcelona, Publ. de l'Abadia de Montserrat).

Torelli, Pietro (1947): Lezioni di storia del diritto italiano. Diritto privato, la famiglia (Milano, Giuffrè).

Toubert, Pierre (2006): "La institución del matrimonio cristiano desde la Antigüedad tardía al año mil” en Toubert, Pierre (ed.), Europa en su primer crecimiento (Trad. Antoni Domènech, Valencia, U. de Valencia) pp. 225-253.

Toubert, Pierre (1973): Les structures du Latium médiéval (Roma, École Française).

Treggiari, Susan (1993): Roman Marriage, iusti Coniuges From the Time of Cicero to the Time of Ulpian (Oxford, Clarendon).

Vial-Dumas, Manuel (2010): "Familia, muerte y matrimonio, de la familia extensa de la Roma arcaica a la familia nuclear de la Antigüedad tardía”, Revista chilena de historia del derecho, 22: pp. 287-317.

Vial-Dumas, Manuel (2014a): "La revolución de la herencia en la Antigüedad tardía”, Ius Fugit, 17: pp. 293-311.

Vial-Dumas, Manuel (2014b): "Parents, Children and Law, Patria Potestas and Emancipation in the Christian Mediterranean at Late Antiquity and Early Middle Ages", Journal of Family History, 39, Vol. 4: pp. 307-329.

Vial-Dumas, Manuel (2017): "La herencia en la tradición jurídica occidental, algunos momentos estelares", en Martínez-Zorrilla, David y Vial-Dumas, Manuel (ed.) Las múltiples caras de la herencia (Barcelona, Huygens) pp. 23-44.

Violante, Cinzio (1984): "Alcune caratteristiche delle strutture familiari in Lombardia, Emilia e Toscana durante i secoli IX-XII”, en Duby, George y LE Goff, Jacques (ed), Famiglia e parentela nell'Italia medievale (Bologna, Il Mulino) pp. 19-82.

Vismara, Giulio (1978): Il diritto di famiglia in Italia dalle Riforme ai codici (Milano, Giuffrè). 
VIAL-Dumas, Manuel — "La familia nuclear ante el derecho. Una retrospectiva de su formación y definición..."

VISMARA, Giulio (1988): "La successione volontaria nelle leggi barbariche" en VV.AA., Scritti di storia giuridica, 6 (Milano, Giuffrè) pp. 109-143.

VIsmara, Giulio (1935): "La donazione nuziale nel diritto ebraico e nelle fonti cristiane in relazione al diritto romano postclassico" en RoBerTi, Melchiorre (ed.) Cristianesimo e diritto romano (Milano, Vita e pensiero) pp. 295-406.

VocI, Pasquale (1985): "Storia della 'patria potestas' da Costantino a Giustiniano", SDHI, 50: pp. 1-72.

Wicкнам, Christopher (2009): Una historia nueva de la Alta Edad Media (Trad. Tomas Fernández y Beatriz Eguibar, Barcelona: Crítica).

Zeumer, Karl (1944): Historia de la legislación visigoda (trad. Carlos Clavería, Barcelona, Impr. A. Ortega). 